\title{
Emanueli chamber: moist chamber for germination and initial seedling development
}

\section{Câmara de Emanueli: câmara úmida para germinação e desenvolvimento inicial da plântula}

\begin{abstract}
Emanueli Alexandra Prigol de ARAUJO'1; Marli A. RANAL ${ }^{2}$
${ }^{1}$ Engenheira Agrônoma; Sistema Estadual de Meio Ambiente e Recursos Hídricos, Secretaria de Estado de Meio Ambiente e Desenvolvimento Sustentável de Minas Gerais, Superintendência Regional de Meio Ambiente - SUPRAM Triângulo Mineiro, Diretoria de Regularização Ambiental, Praça Tubal Vilela 3, 38400-186 Uberlândia, MG, Brasil; emanueli.araujo@meioambiente.mg.gov.br

${ }^{2}$ Autor para correspondência; Doutora em Ciências; Universidade Federal de Uberlândia, Avenida João Naves de Ávila 2121 38400-902 Uberlândia, MG, Brasil; marliranal@gmail.com
\end{abstract}

Recebido em: 23-10-2020; Aceito em: 20-02-2021

\begin{abstract}
Water is one of the essential requirements to start the germination process and should be supplied to seeds without oscillations to permit comparisons among laboratories. One way to achieve this is by means of a moist chamber for each experimental plot. Emanueli chamber is a low-cost device, designed to evaluate the germination process and the first phases of seedling development. Its advantage is that it reduces daily oscillations in the water content of the germination substrate (filter paper). It is made of two plastic cylindric containers. The larger contains water or other test solution and the smaller, bottomless, stays inside the larger one. The upper part of this smaller container is the support of the filter paper that is maintained uniform and constantly moistened by means of a continuous stem submerged in the liquid of the larger container.
\end{abstract}

Additional keywords: germination moist chamber; seed germination; seed imbibition.

\begin{abstract}
Resumo
Água é um dos requisitos essenciais para desencadear o processo de germinação e deve ser fornecida às sementes sem oscilações, para permitir comparações entre laboratórios. Uma das alternativas para isto é o uso de uma câmara úmida para cada parcela experimental. A câmara de Emanueli é um dispositivo de baixo custo, projetado para avaliar o processo de germinação e as primeiras fases do desenvolvimento de plântulas. Sua vantagem é que reduz as oscilações diárias no teor de água do substrato de germinação (papel filtro). É constituída de dois recipientes cilíndricos de plástico. O maior contém a água ou outra solução de teste e o menor, sem fundo, permanece dentro do maior. A parte superior do recipiente menor é utilizada como suporte para o papel filtro que é mantido uniforme e constantemente umedecido por meio de uma haste contínua, submersa no líquido do recipiente maior.
\end{abstract}

Palavras-chave adicionais: câmara úmida de germinação; embebição de sementes; germinação de sementes.

\section{Introduction}

Water is one of the essential requirements to start the germination process (Baskin \& Baskin, 1998; Bewley et al., 2000, 2013; Brazil, 2009; Elias et al., 2012). Because of this, the relationship between water and the germination process was, and actually still is, the focus of numerous studies that deal with the resumption of metabolism by the embryo, because without water the molecules and metabolic routes remain disabled (Baskin \& Baskin, 1998; Bewley et al., 2000, 2013; Ribeiro-Oliveira et al., 2020). Besides plastic bags and containers suggested to protect the samples of desiccation, there are several types of germination chambers with photoperiod, temperature and humidity control, but these devices do not eliminate the necessity of daily care to maintain the experimental units with water without oscillations (Elias et al., 2012). This is important because germination may be inhibited if the amount of water is inadequate, either too little or too much, leading the seeds to dormancy or death, in both laboratory or field conditions (Baskin \& Baskin, 1998). Therefore, the regulatory agencies of methods and techniques on seed germination insert instructions in their publications so that the water content does not oscillate during the experimental period (ISTA, 2007; Brasil, 2009).

An important review about the art and science of seed testing is the focus of the book of Elias et al. (2012). According to these authors, the first seed testing laboratory was established in Saxony, Germany in 1869; then in America, in the Connecticut Agricultural Experiment Station in 1876; and the first one in Ottawa, Canada in 1902. They also present the complete history about seed testing organizations, created in the early 
1900s, with emphasis on ISTA (International Seed Testing Association), the most important world-wide organization dedicated to seed testing on an international scope. The Association of Official Seed Analysts (AOSA), an organization composed of official state, federal and University member laboratories of United States of America and Canada; the Society of Commercial Seed Technologists (SCST), an organization of seed technologists from private and commercial seed laboratories, also of the U.S.A. and Canada; the American Seed Trade Association (ASTA) and the Commercial Seed Analysts Association of Canada (CSAAC), among others, were mentioned by these authors as our important seed historical legacy. This information shows that since the end of the $19^{\text {th }}$ century scientists and technologists are promoting and facilitating uniformity of seed testing results that permit comparisons among laboratories around the world.

In general, containers used for seed germination studies (or other diaspores) are made of glass or acrylic. Besides being expensive, another inconvenience is that these conventional containers do not maintain the humidity of the germination substrate unless maintenance is done periodically. As mentioned above, the oscillation in the water content of the substrate is one of the major problems in seed laboratories. This causes negative modifications due to the desiccation or soaking during the seed imbibition process, decreasing the accuracy of the germination and development measurements.

To solve this problem, the idea to build the Emanueli chamber came about. During the second semester of 2000 , involving students from the fourth period of the Agronomy Course of the Federal University of Uberlândia, who were taking the discipline of Plant Physiology, taught by the second author, the insight occurred. They were given the task of assembling some device that would allow them to evaluate the seed germination process, without any change in the water content of the substrate, from the beginning to the end of the experiment, and without fungal contamination. A student from that class, the first author of this paper, had the insight and presented her invention at the end of the semester.

Years later, the Professor was invited by a former technician from one of the University's laboratories to file a patent application for an invention made with the students. Thinking about the possibility of making such a useful and low-cost invention public, the Professor invited the student to gather the necessary documents. After that, they entered a patent application with the $\mathrm{Na}$ tional Institute of Industrial Property - INPI. Since 2005 the patent application protocol was renewed annually.

In 2019 came the rejection of the patent, because a 1982 American patent was found (Holtkamp, 1982) for a device that allows the maintenance of moisture in vessels by capillarity. This patent was modified by its author, generating a second number (Holtkamp, 1984). The description of the aforementioned device published in 1982 and 1984 is not a moist chamber, but a vessel kept on a water support. Although there was the possibility of arguing with INPI, we chose to terminate the patenting process and send this technical note that will be more helpful to laboratories than obtaining a patent.

It is important to make it clear that during these 14 years (2005 to 2019) the online search engines have been improved, giving INPI the certainty that nothing similar had been patented before. This careful search by INPI guarantees the originality of the invention described in this note. It is also important to inform that during the period in which the process remained with INPI, the protocol number was properly used in our publications (Mendes-Rodrigues et al., 2010; Ranal et al., 2016).

Inventions, large or small, arise from insights generated by some specific need or by some keener look at natural or artificial phenomena. Maintaining the proper proportions, the insight that produced the Emanueli chamber reminds us of the history of Petri dishes, a ubiquitous item of microbiology laboratories. When Richard Julius Petri was serving as an assistant of Robert Koch, he modified the plating technique of Koch whose description was published in 1887, but some bacteriologists claimed self-recognition for this invention (Shama, 2019). Recovering the history of the Petri dish and the first years of Microbiology, Oliveira et al. (2018) and Shama (2019) showed that this is another case of simultaneous discovery. Simultaneous insights are common in several knowledge areas because when multiple minds try to solve similar problems, different paths can lead to similar solutions.

Since we are living at the height of the communication era, we can minimize the inconvenient phenomena of simultaneous discoveries. Due to the lack of access to information, requests for authorship for the same or similar inventions happened quite often over the last three centuries of research. Thus, we feel the importance and urgency in describing the device created, not only to ensure its authorship, but to expand the possibility of its use in laboratories that study the germination process of seeds and other diaspores.

\section{Emanueli chamber description}

The Emanueli chamber is a low-cost device that solves the problem of oscillation of humidity of the germination substrate (qualitative filter paper, weight 80 g) because the humidity stays uniform and constant during the experimental period, allowing the measuring of the germination process with accuracy (Figura $1 \mathrm{~A}-\mathrm{E}$ ).

This moist chamber is made of two plastic cylindric containers. One is larger and transparent to permit light penetration. It has a lid and is the water, or other test solution, reservoir. The second cylindric container is smaller, also made of plastic, transparent or white, and stays inside of the larger container. It is bottomless to avoid floating and is lidless. The upper part of this smaller container is the support of the filter paper used as the germination substrate. The filter paper is maintained uniformly and constantly moistened by means of a continuous stem submerged in the liquid of the larger container. 


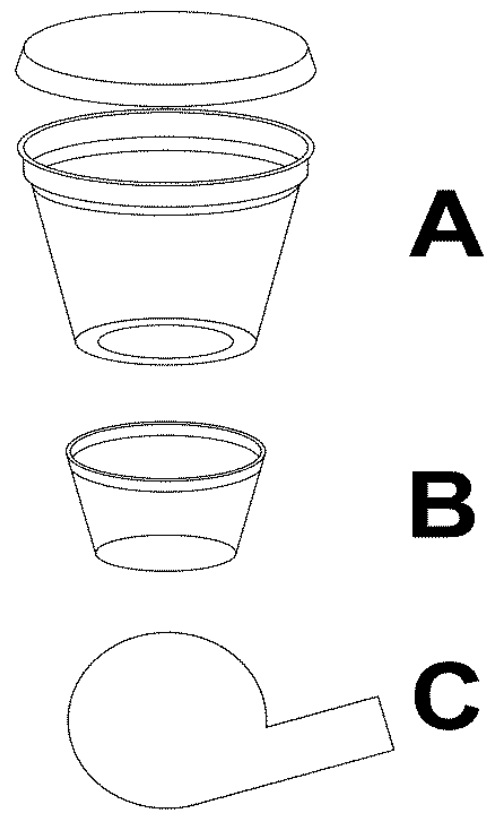

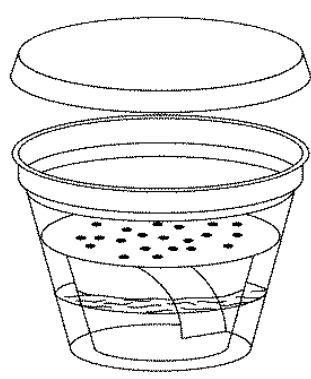

D

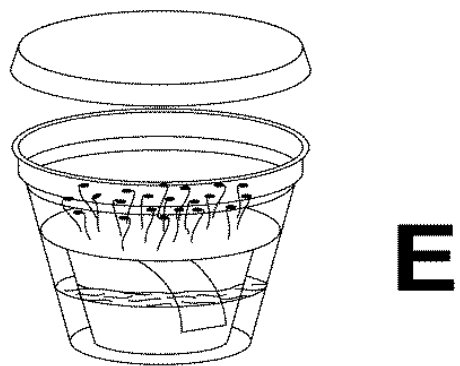

Figure 1 - Schematic view of the Emanueli Chamber. A. Larger container with lid, used as a water or solution reservoir that is to be used for seed germination and initial seedling development. B. Smaller container, without a lid and bottom. C. Superior schematic view of the filter paper with continuous stem. D. Emanueli chamber mounted with seeds on the filter paper and water or solution contained in the larger container. E. Emanueli chamber mounted with seedlings on the filter paper and water or solution contained in the larger container.

The liquid of the reservoir (larger container) must occupy from 20 to $60 \%$ of the total volume of the container, depending on how often the researcher wants to replenish the liquid. Special care should be taken that the maximum liquid level does not exceed the height of the smaller container. If the water level exceeds the height of the smaller container, there will be soaking of the filter paper and the seeds may fall into the reservoir liquid, which will make the evaluation unfeasi- ble. Special care also should be taken so that the paper stem remains immersed in the water or solution in the larger container throughout the experimental period to avoid dryness.

This device has been successfully used in the laboratory since 2001, both due to the constancy in water availability and the low incidence of fungi in the filter paper that is the substrate for germination (Fig. 2A-E). Its low construction cost is also noteworthy.
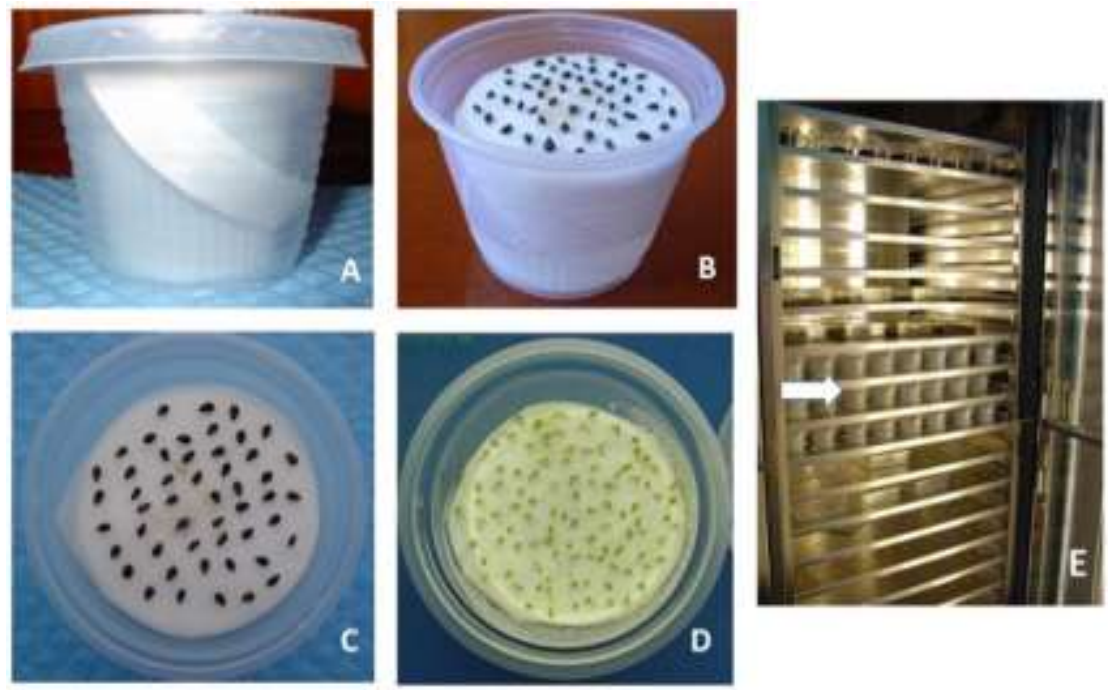

Figure 2 - Emanueli chamber. A. Filter paper with stem on inner of the moist chamber. B- C. Seeds of black sesame sowed over the filter paper and inside of the moist chamber. D. Seedlings of Miconia sp. (Melastomataceae) over the filter paper and inside of the moist chamber. E. Germination chamber with several Emanueli chambers of one experiment. 
For small seeds such as some Asteraceae, Melastomataceae, some Poaceae, Pedaliaceae, Urticaceae and similar ones, the larger container may be $7 \mathrm{~cm}$ in diameter in the largest portion (top) and $5 \mathrm{~cm}$ high, with a volume of up to $100 \mathrm{~mL}$. The smaller container, with a capacity of $50 \mathrm{~mL}$, must be $5 \mathrm{~cm}$ in diameter at the top and between 3 and $4 \mathrm{~cm}$ tall, depending on whether only germination is evaluated or if the initial growth of the seedling will also be monitored. The filter paper, about $5.2 \mathrm{~cm}$ in diameter, should be placed at the top of this smaller container. These dimensions (seeds smaller than $2 \mathrm{~mm}$ ) allow the sowing of 50 well-spaced or 100 more grouped seeds, and these are very representative samples for each experimental plot. The length of the filter paper stem must be compatible with the height of the smaller container to remain immersed in water. As initial asepsis, the seeds should be washed in distilled water and sowing should be done using only well-formed seeds. For larger dispersal units (seeds or diaspores), larger containers can be used, with the care of placing an internal holder in the smaller container so that the filter paper does not bend inwards, soaking the diaspores in the water or solution contained in the larger container.

\section{Acknowledgments}

The first author thanks her colleagues who participated in her work team and who helped her realize her idea. The second author thanks the numerous students, interns and fellows who tested the efficiency of the device in laboratory. Special thanks go to Clesnan Mendes Rodrigues and João Paulo Ribeiro de Oliveira for their encouragement to publish this communication. Both authors thank Roger Hutchings for reviewing the English version of the manuscript.

\section{References}

Baskin CC, Baskin JM (1998) Seeds: ecology, biogeography, and evolution of dormancy and germination. Academic Press. 666p.

Bewley JD, Bradford KJ, Hilhorst HWM, Nonogaki H (2013) Seeds: physiology of development, germination and dormancy, 3rd ed, Springer. 392p.

Bewley JD, Hempel FD, McCormick S, Zambryski P (2000) Reproductive development. In: Buchanan BB, Gruissem W, Jone RL (eds) Biochemistry and molecular biology of plants, American Society of Plant Physiologists. p.988-1043.
Brasil (2009) Regras para análise de sementes. Ministério da Agricultura, Pecuária e Abastecimento. MAPA/ACS. 399p.

Elias SG, Copeland LO, McDonald MB, Baalbaki RZ (2012) Seed testing: principles and practices. Michigan State University Press. 368p.

Holtkamp R (1982) Capillary disc and support therefor. United States Patent number 4343109. Aug 101982. Available at <http:/www.freepatentsonline.com/4343109.html> (accessed nov 03 2019).

Holtkamp R (1984) Capillary disc and support therefor. United States Patent number 4434577. Mar 061984. Available $<$ https://patents.google.com/patent/US4434577A/en> (accessed nov 03 2019).

ISTA - International Seed Testing Association (2007) ISTA Method Validation for Seed Testing. Available at <https://www.seedtest.org/upload/cms/user/ ISTAMethodValidationforSeedTesting-V1.01.pdf> (accessed fev 12 2021).

Mendes-Rodrigues C, Araújo FP, Barbosa-Souza C, Barbosa-Souza V, Ranal MA, Santana DG, Oliveira PE (2010) Multiple dormancy and maternal effect on Miconia ferruginata (Melastomataceae) seed germination, Serra de Caldas Novas, Goiás, Brazil. Revista Brasileira de Botânica 33(1):93-105. https://doi.org/10.1590/S0100-84042010000100009

Oliveira IT, Zuccheratto KMC, Granado IZ, Mello PH, Oliveira HPM (2018) De onde vêm os nomes das vidrarias de laboratório? Química Nova 41(8):933-942. http://dx.doi.org/10.21577/0100-4042.20170240

Ranal MA, Mendes-Rodrigues C, Teixeira WF, Oliveira AP, Romero R (2016) Seed germination of Microlicia fasciculata, an apomictic and aluminium accumulator species: unexpected intraspecific variability in a restricted Neotropical savanna area. Flora 220:8-16. https://doi.org/10.1016/j.flora.2016.02.001

Ribeiro-Oliveira JP, Ranal MA, Boselli MA (2020) Water dynamics on germinating diaspores: physiological perspectives from biophysical measurements. Plant Phenomics. https://doi.org/10.34133/2020/5196176

Shama G (2019) The "Petri" dish: a case of simultaneous invention in Bacteriology. Endeavour 43:11-16. https://doi.org/10.1016/j.endeavour.2019.04.001 